\title{
PANTALON CAMPURAN DENGAN METODE TWISTING PATTERN UNTUK PENJAHIT GANG OPEK
}

\author{
Rudy Trisno ${ }^{1}$, Clinton Thedyardi $^{2}$ dan Irene Syona Darmady ${ }^{3}$ \\ ${ }^{1}$ Jurusan Arsitektur, Universitas Tarumanagra Jakarta \\ Email: rudyt@ft.untar.ac.id \\ ${ }^{2}$ Jurusan Arsitektur, Universitas Tarumanagra Jakarta \\ Email: clinton.thedyardi@gmail.com \\ ${ }^{3}$ Jurusan Arsitektur, Universitas Tarumanagra Jakarta \\ Email: irenesyona@gmail.com
}

\begin{abstract}
ABSTRAK
Kelompok Penjahit Gang Opek adalah kumpulan beberapa penjahit keliling yang mereparasi celana dan masih tersisa belakangan ini. Sebuah isu kompetisi pasar jahitan di daerah produksi pakaian menyebabkan berkurangnya order. Masalahnya, mereka perlahan berganti profesi, atau mencoba menerima order lain untuk menyambung hidup. Jenis pekerjaan yang kerap mereka terima adalah reparasi pantalon. Pantalon adalah istilah pakaian yang merujuk pada sebuah jenis celana yang panjangnya semata kaki. Namun demikian, permintaan pasar kian kompleks, jenis pekerjaan yang mereka kerjakan kian menyusut. Temuannya, penjahit keliling mengalami kesulitan membuat pantalon dengan design baru karena hanya terbiasa untuk memperbaiki. Untuk mengatasi masalah tersebut, sebuah pelatihan pantalon dengan menekankan pada pola, struktur dan volume menawarkan pengembangkan cara berpikir meruang. Hal ini sekaligus mempertanyakan cara berpikir dalam perancangan pakaian yang kerap mengklaim penggunaan ilmu arsitektur sebagai inspirasi saja. Maka dari itu, cara berpikir meruang diterjemahkan melalui pengembangan metode twisting untuk menghasilkan volume pantalon yang dapat dikembangkan untuk menghasilkan perspektif keruangan melalui pecah pola dan penggunaan detail berbeda: misalnya pola - pola rok, sarung, kargo, celana pendek, atau apron . Pola pantalon pada kesempatan ini dikombinasikan untuk menghasilkan kebaruan berupa volume dan kegunaan pantalon untuk keruangan berbeda, sehingga dapat digunakan untuk aktivitas berbeda pula. Teknik twisting pola pantalon jenis pensil dikombinasikan dengan pattern making software berbasis cad, dan dikembangkan sketsanya pada powerpoint presentation. Hasilnya akan menjadi pantalon contoh yang menjadi sebuah kritik atas stagnansi rancangan pantalon di Indonesia.
\end{abstract}

Kata Kunci: Arsitektural; Pantalon; Pelatihan; Penjahit.

\section{PENDAHULUAN}

Kelompok penjahit gang Opek adalah beberapa kumpulan penjahit keliling yang masih tersisa di daerah Jakarta Selatan. Kelompok penjahit keliling adalah sebuah fenomena kehadiran penjahit keliling masih bertahan sampai saat ini. Kehadiran mereka pernah sangat membantu di masa lalu dengan memberikan pelayanan sampai ke pintu rumah. Namun demikian, isu ketatnya kompetisi industri pakaian di masa kini, menjadikan sebagian dari penjahit keliling sekitar telah berganti profesi atau menyerah pada nasib. Hal ini disebabkan oleh ketimpangan ekonomi dan tingkat pendidikan penjahit keliling. Dengan kondisi yang serba terbatas, tambahan pengetahuan dan peluang untuk membuat pantalon sulit didapatkan oleh mereka demi mengaktualisasi kemampuan. Hilangnya profesi mereka sama dengan masalah hilangnya penjahit keliling dari lingkungan rumah tinggal kita. Hal ini tidak saja mengurangi fasilitas sosial, namun juga keterampilan lokal dan tumbuhnya pengangguran. 
Para penjahit keliling adalah tenaga produktif yang sangat berguna untuk mendukung kebutuhan pasar. Karakter mereka yang mobile, harga ekonomis dan waktu flexible adalah sebuah fakta yang berpotensi mengisi celah kebutuhan industri pakaian yang dapat datang tiba - tiba dan hilang begitu saja. Tambahan pengetahuan perlu diberikan kepada kelompok penjahit gang Opek agar memberikan kesempatan kembali prospek untuk menjadi tenaga kerja yang handal (Bloch, 2011). Tambahan pengetahuan bagi penjahit keliling dapat membuka celah peluang bagi mereka untuk mempertahankan profesinya atau bahkan menjadi penjahit tetap di masa yang akan datang. Hal lain yang perlu dipertimbangkan adalah kondisi pasar di sekitar yang merujuk pada tumbuhnya butik - butik perancang busana yang banyak membuka usaha di sekitar mereka. Meski peluang mendapatkan pekerja baru lebih terbuka, harga yang lebih kompetitifpun muncul karena ketersediaan penjahit meningkat. Sebuah pelatihan yang tepat guna merupakan salah satu usaha untuk menyelamatkan profesi penjahit keliling khususnya di gang Opek, sementara memberikan kesempatan lain untuk menjadi pekerja tetap. Kemungkinan lain perlu dipikirkan karena disadari bahwa rencana jangka panjang perlu dilakukan sehingga dapat memberikan manfaat keberlanjutan dan efek yang lebih besar (Doğan, 2012) kepada kelompok penjahit keliling di gang Opek.

Sebuah pelatihan pantalon ditawarkan bagi kelompok penjahit keliling gang Opek dengan berpikir meruang dengan pola, struktur dan volume. Hal ini dilatar belakangi juga atas ketersendatan perkembangan desain pantalon yang sering kali berjalan di tempat. Titik berat dilakukan pada pembuatan pola untuk pantalon dengan menyatukan beberapa tipe bawahan dan menyisipkan fungsi tambahan pada struktur pantalon dasar yang dimiliki penjahit sehingga menghasilkan volume meruang yang baru. Memang benar, pelatihan ini belum sepenuhnya menjamin keberlangsungan profesi penjahit, namun secara umum memberikan pengetahuan design pantalon bagi kelompok penjahit agar tidak sekedar mahir memperbaiki pantalon atau jeans namun juga bekerja menggunakan kreativitas (Grassby, 2005). Pengetahuan akan pola dengan cara berpikir meruang pada pantalon akan dikombinasikan dengan bahan dan teknik yang tidak umum digunakan penjahit keliling agar pengetahuan mereka berkembang (Doğan, 2012), dan bukan tidak mungkin menjadi proses seleksi kepada mereka yang bekerja dengan baik. Dengan demikian, penjahit pantalon gang Opek akan mulai mempelajari cara - cara baru membuat bawahan lain, termasuk memadukannya menjadi pola pantalon kreatif.

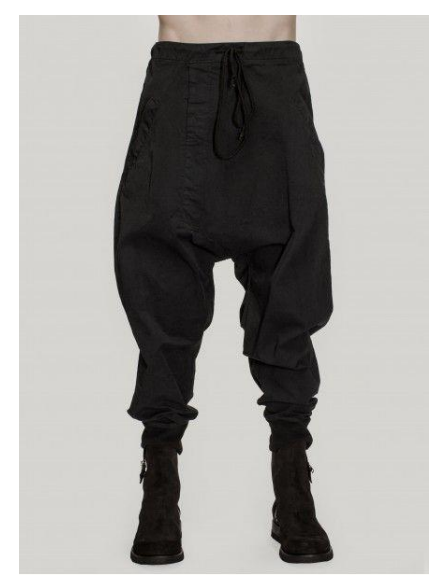

Gambar 1. Kreativitas Manipulasi Pola Struktur Pantalon

Sumber: https://cruvoir.com/collections/frontpage/products/trousers-grimm diunduh 21 Januari 2019. 
Sebuah pantalon ditargetkan untuk pelatihan yakni sampel jenis pensil yang menungkik tajam pada bagian bawah, sementara memberikan keleluasaan pada bagian pinggang. Gagasan lain adalah memberikan sentuhan struktur lipit dengan lipatan tajam dan siluet kurva linear pada bagian belakang. Dengan rancangan yang cukup kompleks, arahan desain memberi inspirasi untuk memadukan berbagai elemen bawahan untuk menjadi pantalon: rok, apron, sarung dan pantalon pensil. Hal ini menjadi sulit bagi perancang maupun penjahit, sehingga pembuatan pola perlu dibantu dengan komputasi desain agar presisi dan mengurangi kesalahan perhitungan. Pelatihan ini memberikan pengetahuan cara membuat pola dengan teknik digital yang sering digunakan di bidang arsitektur. Selain itu modifikasi tipe dan program akan memberikan sumbangsih berupa fungsi dan gaya baru pada pantalon. Dengan kompleksitas baru pada cara berpikir dan implentasi pola untuk menghasilkan keruangan, hal ini memberikan wawasan baru kepada penjahit keliling dan menjadi bahan untuk membuat produk dengan design yang lebih maju (Oestigaard, 2004) dan berkelanjutan (Clarke, 2018). Lebih jauh lagi, cara berpikir meruang sebagai metode memperkaya dunia fashion membuka celah stagnansi perkembangan fashion yang kerap mengambil arsitektur sebagai objek inpirasi saja (Paksoy \& Yalcn, 2005)

\section{RUMUSAN PERMASALAHAN}

Kelompok penjahit gang Opek berada pada situasi yang tidak menguntungkan, beberapa permasalahan mitra secara umum:1) Penghasilan mereka yang bergantung hanya pada reparasi umumnya hanya cukup menyambung hidup. 2) Kelompok penjahit hanya mengandalkan keterampilan memperbaiki dan memiliki pengetahuan terbatas untuk membuat pantalon. 3) Keterbatasan jaringan pekerjaan dan kemampuan terbatas saat ini membuat penjahit bekerja hanya di sekitar lingkungan, mereka bergantung pada teman, tetangga, dan masyarakat sekitar yang kebetulan butuh untuk memperbaiki pantalon dan pada saat tertentu bila pelanggan secara khusus sedang menunggu kedatangan mereka. Berdasarkan pengalaman, kelompok penjahit ini beberapa kali mendapat tawaran membuat pantalon; Namun karena kebutuhannya tidak berkelanjutan, mereka kembali mengandalkan profesi penjahit keliling. Gang Opek pernah menjadi tempat mereka mengumpulkan order, salah satunya karena menjadi tempat tinggal beberapa penjahit. Kegiatan pengabdian kepada masyarakat ini bermaksud membuka celah pelatihan untuk menyambung hubungan kelompok penjahit dengan perancang busana di sekitar lingkungan agar kelompok penjahit dapat meningkatkan nilai guna dan menjual jasa mereka secara berkelanjutan (Zabala-Iturriagagoitia, 2012). Tambahan pengetahuan mengenai hubungan keruangan dan pantalon menginisiasi pelatihan ini agar penjahit siap untuk menerima tawaran pekerjaan dari perancang. Melalui komunikasi dan negosiasi antara perancang, kelompok penjahit sepakat membuat sketsa agar dapat dikembangkan menjadi rancangan pola, memilih bahan dan teknologi arsitektural untuk diaplikasikan pada produk yang akan dikreasikan kelompok penjahit.

\section{TINJAUAN PUSTAKA}

Menurut KBBI 2017, pantalon diartikan sebagai celana panjang (Sunendar, 2017). Secara etimologi dideskripsikan pantalon memiliki panjang semata kaki. Pada awalnya, istilah pantalon merujuk pada istilah seni komedi Italia yang menggunakan kaki sebagai lelucon. Pantalon pada saat itu merupakan celana ketat yang kemudian berevolusi menjadi bentuk- bentuk berbeda untuk kebutuhan spesifik. Perubahan trend 2019-2020 merujuk pada pelebaran jenis pantalon dan perpaduan jenis pada sebuah pantalon. Perubahan fisik yang dramatis terjadi dengan memadukan elemen - elemen lain dari bawahan bahkan atasan. Fungsi pantalonpun melebur, sehingga pantalon dapat digunakan untuk aktivitas dan acara yang berbeda. 
Menghadapi mitra dengan tingkat intelektual dan keterampilan terbatas, sebuah langkah dan cara sederhana distrategikan untuk merencanakan penjabaran bergradasi. Secara hati - hati pelatihan pola ditingkatkan kompleksitasnya dengan pengetahuan struktur dan volume sebagai implemntasi cara berpikir meruang. Pengerjaannya secara bertahap disosialisasikan dan didukung contoh - contoh melalui presentasi, agar lebih mudah dicerna dan diingat oleh kelompok penjahit (Oestigaard, 2004). Pantalon contoh dijadikan sample dan akan diimplementasi oleh penjahit agar dapat dikembangkan kemudian. Sementara itu, produksi akan ditawarkan kepada perancang, melalui contoh pengerjaan pola dan sample jahitan bila penjahit telah mahir dan gapah (Bloch, 2011) dalam membuat pantalon. Dengan strategi ini, metode twisting merupakan keluaran bergradasi sebagai pengembangan pola pantalon dasar yang dikuasai penjahit, sementara power point presentation dan pattern making software merupakan alat uji coba memudahkan peleburan tipe pantalon.

Twisting pattern sesungguhnya adalah teknik modifikasi pola dengan mencampur, memadukan, menyatukan pola dari rangkaian model fisik berbeda. Perpaduan dapat dilakukan dengan cara membelokkan, memutus-sambungkan, memutar, mengubah arah sebuah pola untuk disambungkan dengan pola lain yang berbeda. Hasilnya merupakan dua pola kontras yang disatukan. Sehingga twisting pattern bukan dilakukan dengan sekedar menempelkan gambar pola, tapi merencanakan dan mendesain pola yang kontras agar menyambung menjadi satu tanpa menghilangkan karakter pola yang berbeda - beda. Hasil pemolaan ini diakui dapat menghasilkan distorsi, deformasi, perubahan bentuk dan siluet yang sesungguhnya diharapkan untuk secara total mengubah tampilan maupun detail volume dan keruangan pantalon.

Untuk memecahkan masalah mitra, sebuah uji coba pantalon memformulakan solusi sebagai berikut: 1) Memberikan pengetahuan kreatif mengolah pantalon jenis baru, sehingga membuka peluang pengembangan turunan lain; 2) Memberi pelatihan teknik twisting memungkinkan pantalon dikombinasikan dengan dan menjadi rok, sarung, apron, dll sehingga penjahit tidak sekedar terampil dalam memperbaiki pantalon namun juga berinovasi; 3) Mengenalkan lintas disiplin arsitektur dan pakaian selain membuka kesempatan untuk berkenalan dengan toko, workshop, studio agar dapat mengenal dan menemukan pengetahuan dan peluang baru.

\section{METODOLOGI}

Metode kualitatif interpretatif digunakan pada kegiatan ini, khususnya untuk menyelesaikan masalah sasaran dan produk yag dihasilkan. Studi kasus dan kepustakaan digunakan untuk menyempurnakan karya - karya yang sedang trend untuk dimodifikasi dan dipertanyakan permasalahannya. Metode kualitatif interpretatif dalam menginvestigasi dan membuat materi pelatihan merupakan kombinasi setidaknya dua bidang yakni fashion dan arsitektur. Kombinasi kedua bidang akan membantu menghasilkan temuan yang tepat guna sebagai jalan tengah untuk permasalahan penjahit dan kebutuhan industri dari sekedar mengedepankan aspek intelektual semata. 


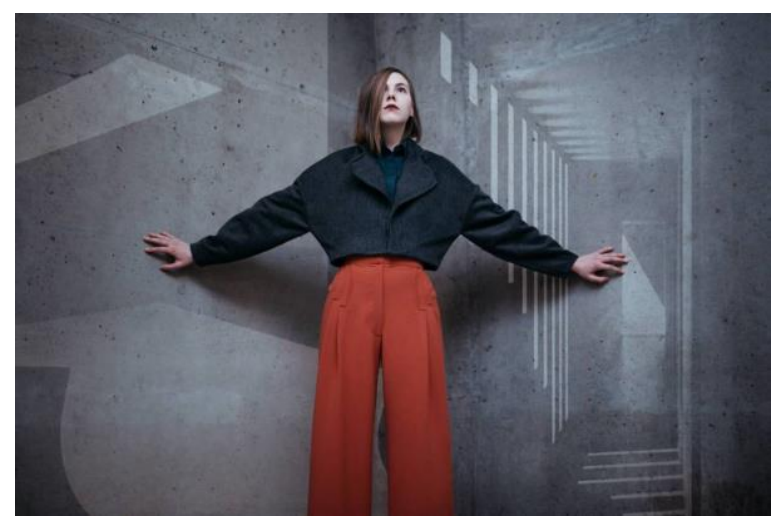

Gambar 2. Architectural Pants.

Sumber: https://www.straight.com/blogra/883891/runway-radar-emily-wong-rejects-fast-fashion-streamlined-piecesinspired-1950s diunduh 21 Januari 2019.

Pelatihan pola memberikan peluang untuk mengurai pengetahuan kepada akar dan sebagai strategi untuk menstimulasi kreatifitas penjahit pantalon dari sekedar bekerja membuat pola yang standar. Secara metodologi, kualitas sebuah pantalon diinterpretasikan dengan:

1) Trend dan gaya pantalon.

Pengertian awam dan sejarah singkat pantalon dengan trend pantalon 2019-2020 yang merupakan pengembangan pantalon campuran.

2) Fungsi dan program pantalon.

Memadukan fungsi baru pada pantalon.

3) Perpaduan tipe.

Interpretasi model pantalon yang dipadukan dengan tipe bawahan lain seperti rok, apron, sarung dan pantolon jenis pensil.

4) Keruangan.

Perpaduan volume dan kegunaan pada acara ataupun aktivitas pada keruangan tertentu, diinterpretasikan oleh perancang busana dan arsitek.

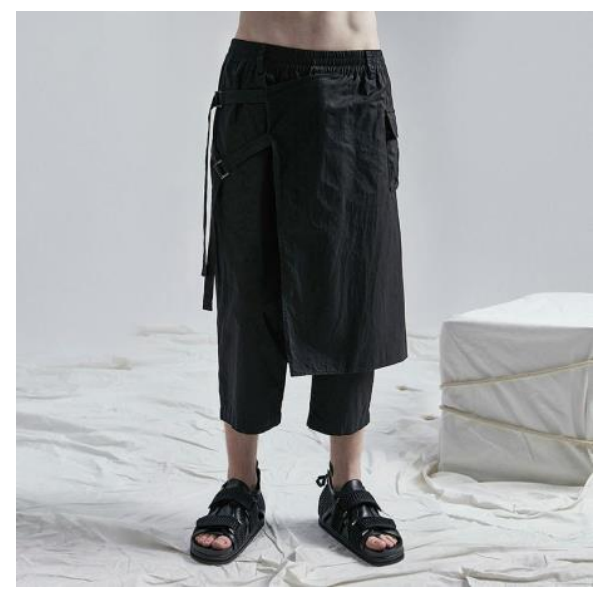

Gambar 3. Deconstructed Pantalon.

Sumber: https://www.dhresource.com/0x0s/f2-albu-g6-M01-8A-A3-rBVaSFs44f6AOlX1AAICtG7YPH0047.jpg/newhairstylist-gd-fashion-men-039-s-wear.jpg diunduh 21 Januari 2019. 
Pelatihan pola pantalon bagi penjahit gang Opek akan mengembangkan hal - hal di bawah ini:

\section{1) Pola Pantalon Dasar dan Desain}

Pelatihan pola pantalon dimulai dengan pola dasar standar yang dijadikan pondasi melatih, tujuannya mengembalikan ingatan penjahit terhadap tata cara baku yang menjadi standar industri. Pola dasar dikembangkan menjadi pola modifikasi kemudian dilakukan twisting berdasar atas sketsa design perancang sehingga lebih mudah diikuti oleh penjahit. Pola adalah gambaran berupa diagram yang mengandung fungsi, design dan proses produksi. Sketsa di sisi lain akan digunakan untuk menjelaskan bentuk dan tipe komponen garmen. Sementara pola dua dimensi bersifat flat perlu disimulasikan pada tubuh bersifat volumetrik agar menghasilkan keluaran yang sinkron. Uraian pola menjadi fokus utama pada kegiatan ini, untuk membantu visualisasi penjahit. Dengan penggunaan alat dan peranti, pattern making software cad, simulasi dan inspirasi dapat disusun menggunakan power point presentation.
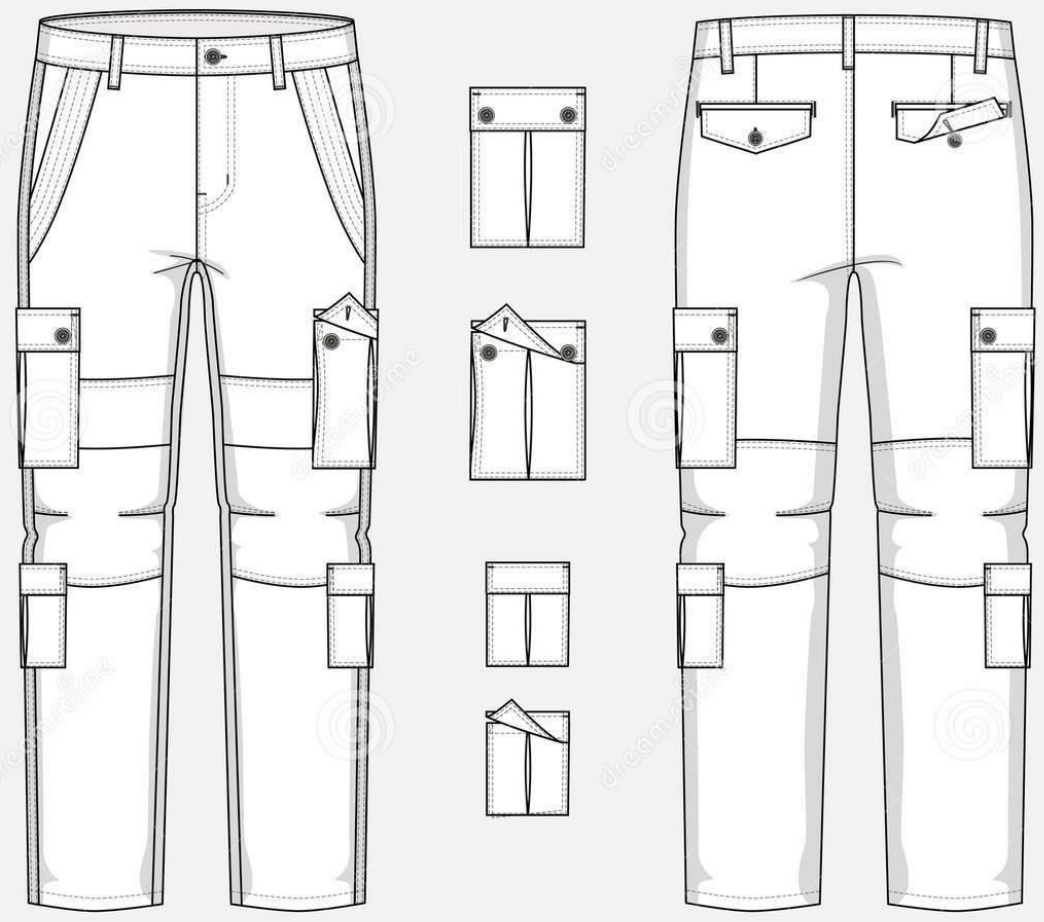

Gambar 4. Pola dan Utility Pantalon.

Sumber: https://www.dreamstime.com/fashion-technical-sketch-men-slim-fit-cargo-pants-patch-pocketsvector-graphic-image115410109 diunduh 21 Januari 2019.

\section{2) Pantalon Contoh.}

Pantalon pilot merupakan hasil kerjasama dan komunikasi antara arsitek, perancang dan mitra. Pola digital digambarkan dan diproses menjadi pola pilot oleh perancang. Proses dilanjutkan dengan membuat pantalon contoh bagi semua penjahit kemudian dimodifikasi dan diturunkan sebagai bahan latihan bersifat edukasional (Ravasi, D. \& Stigliani, 2012) bagi penjahit gang Opek. Pantalon contoh akan dinilai oleh perancang. 


\section{Bahan}

Bahan pola merupakan bahan umum dan sederhana namun menjadi standar industri antara lain: kertas roti, belacu, perca. Alat kerja dasar sebagian kecil dimiliki oleh penjahit namun alat kerja spesifik disiapkan agar pelatihan menjadi seragam. Kertas dan karton menjadi media dalam sketsa pola manual, ditunjukkan proses membuat pola dengan pattern making software pada power point presentation untuk memberikan wawasan baru.

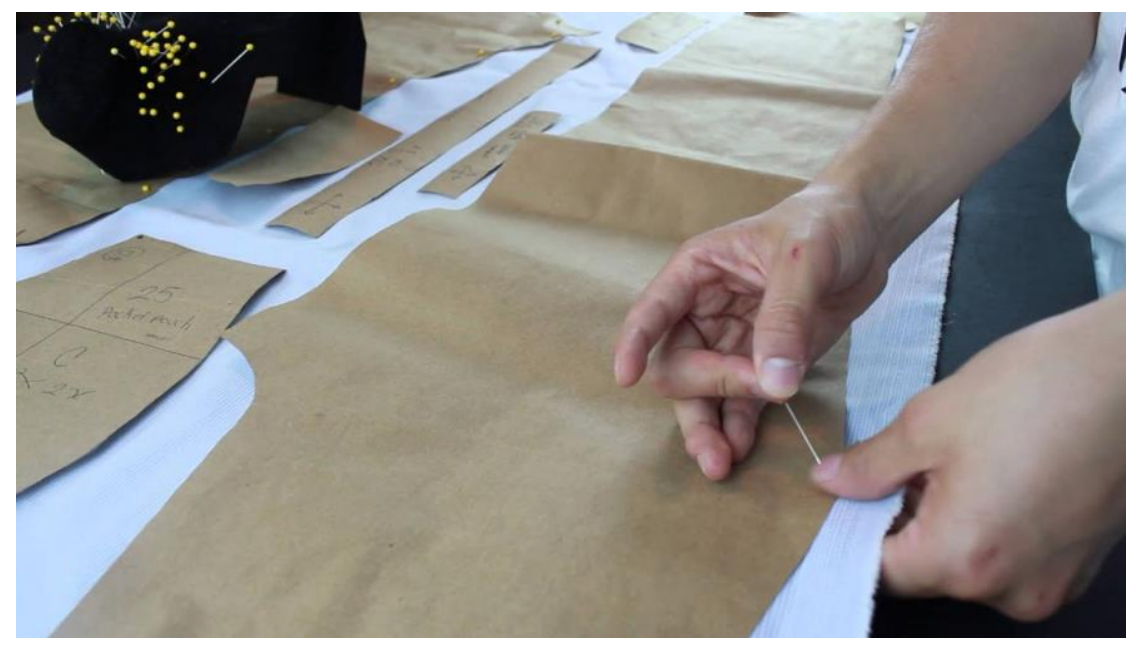

Gambar 5. Proses Pembuatan Pola Pantalon Manual.

Sumber: https://i.ytimg.com/vi/ZQVwe9-KRPI/maxresdefault.jpg diunduh 21 Januari 2019.

Pola yang dihasilkan dari latihan, diuji coba oleh penjahit untuk menjadi turunan pantalon contoh yang diharapkan mendekati pantalon pilot yang disiapkan perancang. Pola belacu diubah menjadi bahan wool, semi-wool, dan gabardin untuk dijalin dan digabung dengan material lain menggunakan teknik menjahit (Gerritsen, A \& Riello, 2014) yang dikuasai penjahit gang Opek. Meski bila melalui sebuah penafsiran ekonomis, pantalon dalam pelatihan membutuhkan biaya lebih tinggi, namun sebuah perencanaan produksi massal di masa depan jelas akan memberikan produktifitas dan efektivitas baik bagi penjahit dan perancang.

\section{HASIL \& PEMBAHASAN}

Perkembangan fashion dan arsitektur di Indonesia masih didominasi oleh cara berpikir terpisah yang memberikan gambaran perpecahan antara dua bidang ini. Sementara fenomena global mempromosikan lintas ilmu yang saling mengisi kekosongan dan kekurangan di antara keduanya sertas menyarankan sebuah integrasi yang berkelanjutan (Clarke, 2018). Meskipun demikian, kerap ditemukan cara pikir arsitektural dalam fashion hanya terbatas sebagai inspirasi saja (Paksoy \& Yalcn, 2005). Arsitektur kerap menjadi sebuah inspirasi yang diterjemahkan sebagai motif dan ornamen sebagai sebuah metafora. Kegiatan ini mempertanyakan relasi antar keduanya dan menawarkan cara pikir baru melalui keterampilan penjahit yang berada pada dasar paramida bidang fashion. Mengkombinasikan ilmu keruangan arsitektur untuk diimplementasikan pada dunia fashion melalui 
cara pikir meruang dengan menghasilkan pola pantalon sehingga menghasilkan struktur dan volume baru dan menjadi metode pendekatan baru dalam fashion.

Mitra yang menjadi sasaran kegiatan ini adalah penjahit keliling gang Opek. Melalui analisis terhadap situasi lingkungan fenomena hadirnya penjahit keliling gang Opek sesungguhnya memberikan manfaat lokal bagi penduduk sekitar. Meskipun isu terhadap hilangnya penjahit keliling dari perkotaan karena masalah terdesaknya mereka karena kompetisi pasar; Sebuah solusi ditawarkan sesungguhnya berupa pembekalan untuk menambah wawasan keterampilan mereka agar dapat berkembang dan beradaptasi dengan situasi. Hal ini dilakukan, sekiranya profesi mereka sekalipun tergerus oleh kompetisi; Penjahit keliling gang Opek dapat terbantu dengan kemampuan mereka masuk ke dalam industri baik menjadi penjahit freelance ataupun menjadi penjahit tetap konveksi atau perancangan busana sekitar.

Melalui investigasi terhadap mitra, pekerjaan penjahit keliling gang Opek terkonsentrasi pada kemampuan reparasi dan jahitan perbaikan pada pantalon. Namun demikian, mereka umumnya menguasai pola pantalon dasar yang berbentuk flat. Mereka pun mengakui kemampuan mereparasi bahan lain seperti kemeja, rok, jeans namun tidak mampu mengerjakan pola rumit. Pekerjaan dilakukan manual, baik dengan mesin klasik jenis butterfly atau singer yang ditambatkan pada meja portable. Maka dari itu sebuah sketsa berupa kumpulan contoh - contoh pantalon yang sedang trend dihimpun untuk memperlihatkan kemungkinan - kemungkinan yang dapat dihasilkan untuk membuat prototipe pantalon.



Gambar 6. Presentasi Trend Pantalon.

Sumber: Tim Abdimas, 2019. 
Dengan menyadari trend yang berubah - ubah dari pantalon dan fungsi - fungsi campuran yang terjadi pada trend global; Sebuah diskusi kelompok dilakukan untuk mengembangkan kompleksitas prototipe pantalon berdasarkan kemampuan penjahit keliling mereparasi dan membuat pantalon dasar. Hal ini dilakukan agar sketsa dan pola yang dibuat menjadi hasil kompromi yang mengkombinasikan beberapa detail pakaian berbeda pada pantalon. Detail rok, detail sarung, pantalon pensil, apron dan jubah dikreasikan menjadi pantalon yang dapat ditransformasikan atau memiliki dua atau lebih sisi pakaian. Melalui sketsa dapat dijelaskan kemungkinan dan peluang - peluang baru mengkreasikan pantalon, dengan cara mengkombinasikan jenis pola dan detail - detail pakaian lain sebagai media belajar.

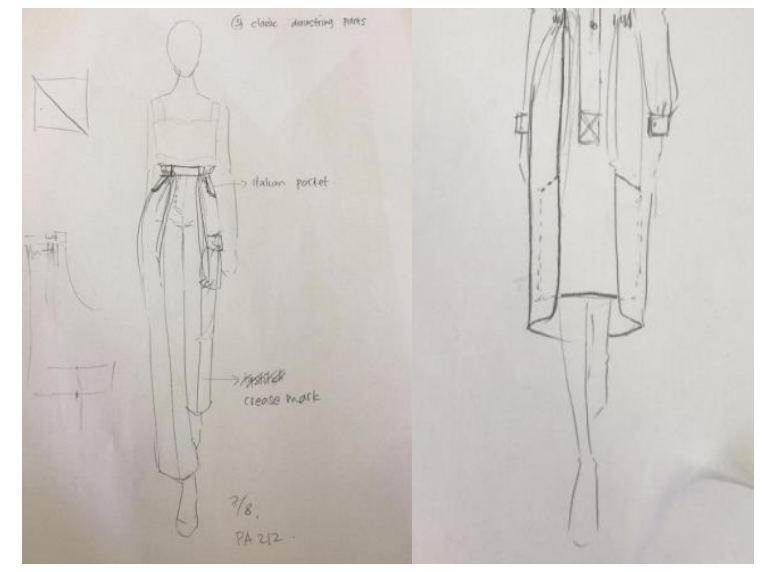

Gambar 7. Sketsa Pantalon dan Turunannya. Sumber : Tim Abdimas, 2019.

Setelah memperoleh sketsa pantalon utama, dilakukanlah survey mengenai bahan yang cocok digunakan untuk membuat pantalon. Untuk menghasilkan pantalon berkualitas, dicarilah variasi material wool dengan kualitas berbeda untuk dipelajari. Selain itu, tekstur pantalon akan dipilih untuk memberikan variasi dan model yang sesuai dengan trend pantalon. Hal ini bertujuan untuk mengajarkan kelompok penjahit keliling mengenai selera yang bagus terhadap pakaian, sekaligus memperluas kemungkinan - kemungkinan pembelajaran lain karena menggunakan material yang lebih berkualitas.

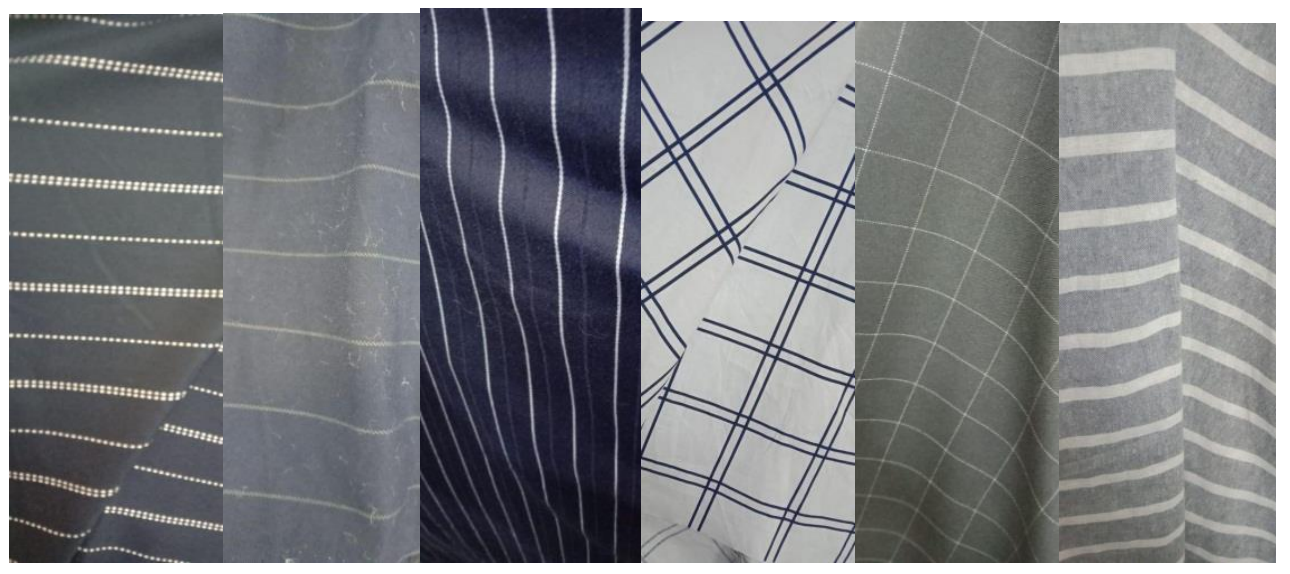

Gambar 8. Survey dan Variasi Bahan Pantalon. Sumber : Tim Abdimas, 2019. 
Untuk menghasilkan pantalon yang dapat ditransformasikan, pilihan detail dan sistem sambungan sangat menentukan. Maka dari itu, survey bahan tidak saja menjadi penting untuk disesuaikan dengan pilihan detail sambungan. Kepaduan ini perlu direncanakan agar menjadi kesatuan dengan desain prototipe pantalon itu sendiri. Melalui investigasi, terpilihlah detail kancing dan model sambungan yang cocok untuk membuat kompleksitas pantalon yang dapat dikreasikan menjadi tipe - tipe bawahan lain. Dengan terpilihnya detail - detail yang berfungsi untuk menyambung, sebuah rangkaian sambungan akan membantu peluang untuk mentransformasikan dan menambahkan fungsi - fungsi tambahan pada pantalon.

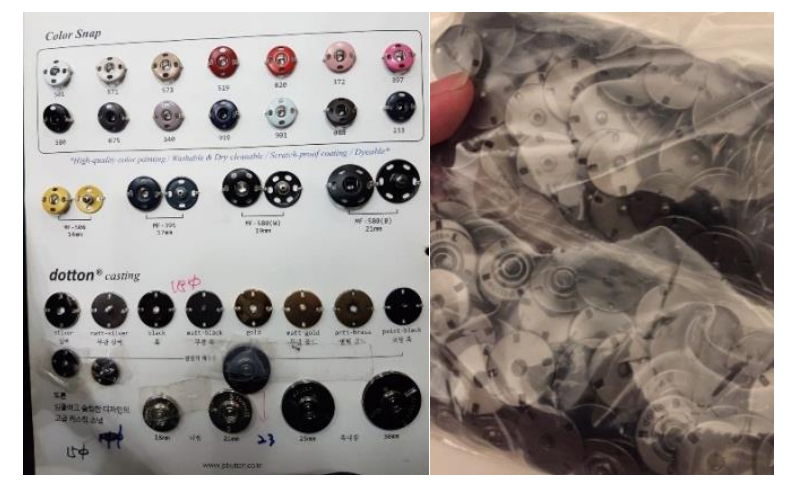

Gambar 9. Variasi dan detail sambungan Pantalon. Sumber : Tim Abdimas, 2019.

Setelah terpilihnya bahan - bahan, proses pembuatan pola dapat diintegrasikan dengan varisasi detail sambungan. Pembuatan pola dasar dilakukan terlebih dulu berdasar atas pengetahuan umum penjahit keliling. Pola dasar ini diperbaiki dengan membuat dasar pantalon berjenis pensil. Dari pola dasar digambar ulang dengan pattern making software menjadi pola digital. Pola digital ini menjadi pola dasar untuk dikombinasikan dengan cara twisting yakni membebankan, memotong dan menyatukan pola pantalon digital dengan pola lain seperti sarung, rok, apron yang telah ditumpang tindihkan. Pola yang terjadi dicetak untuk diuji coba secara manual agar dapat disempurnakan. Proses twisting diuji coba secara manual, agar penggambaran dua dimensi yang berbentuk lembaran dapat menyatu secara benar saat diterjemahkan menjadi volume.

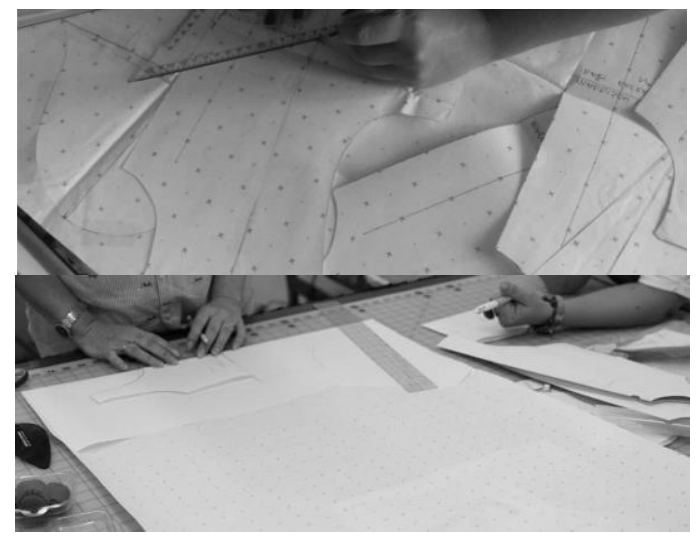

Gambar 10. Studi hasil penggambaran digital Pantalon.

Sumber : Tim Abdimas, 2019. 
Dengan terbukanya kemungkinan perpaduan tipe bawahan untuk dijadikan satu menjadi sebuah pantalon campuran, beberapa temuan pada pecah pola dapat menghasilkan kebaruan: 1) Pertambahan fungsi pantalon 2) Perubahan gaya pantalon 3) Penemuan model pantalon baru. Inovasi dapat dihasilkan berupa pantalon yang mengandung struktur, pola dan potongan campuran namun menggunakan pola utama yakni pantalon itu sendiri.

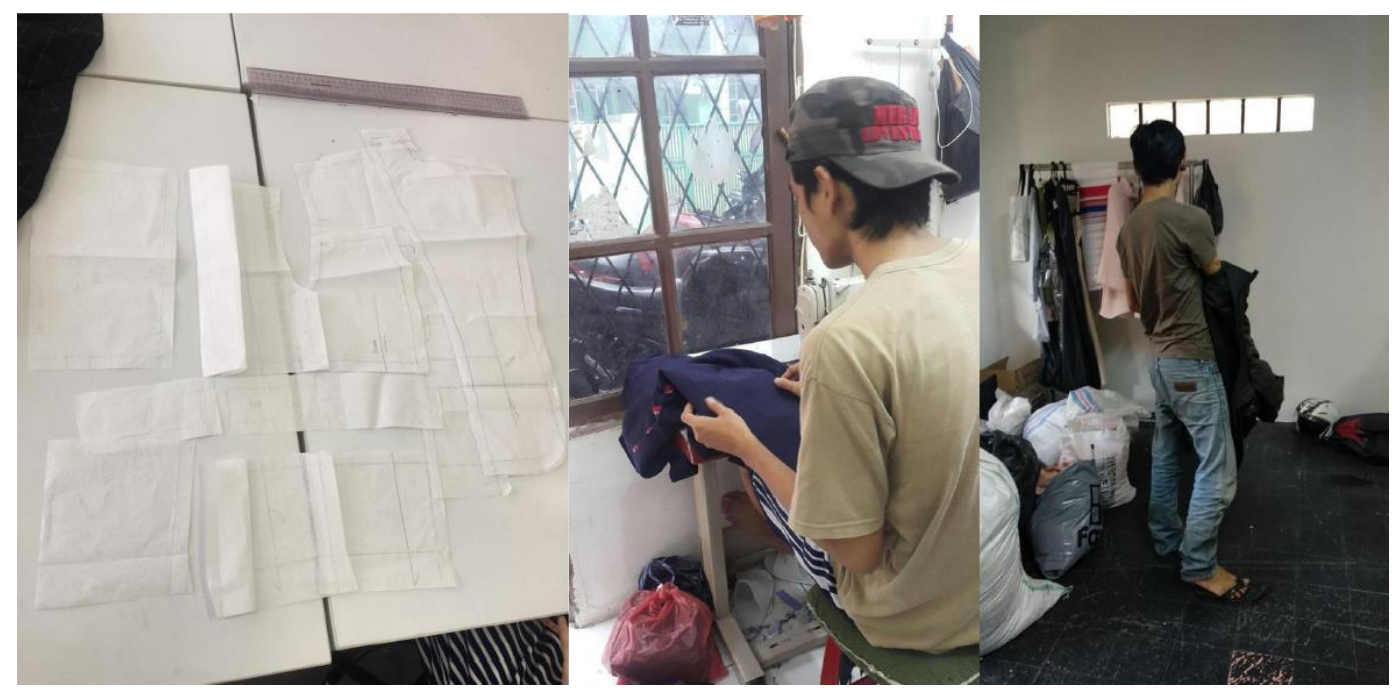

Gambar 11. Pola Twisting Final dan Percobaan MembuatTuruan Pantalon Sumber : Tim Abdimas, 2019

\section{KESIMPULAN \& SARAN}

Program kegiatan Abdimas mengedepankan cara berpikir meruang dalam ilmu arsitektur sebagai pendekatan untuk industri fashion. Cara berpikir ini dituangkan dalam bentuk pola pantalon untuk menghasilkan struktur dan volume baru. Kemampuan penjahit keliling ditingkatkan dengan memberi pengetahuan cara memodifikasi pembuatan pola dasar dengan teknik twisting pola agar dapat melebihi kemampuan sebelumnya yakni reparasi. Pada kegiatan ini teori arsitektur diperkenalkan sebagai cara berpikir untuk pengembangan volume melalui gambar digital dan trend pantalon. Metode produksi secara digital disosialisasikan kepada penjahit pantalon agar dapat meningkatkan produktivitas penjahit serta mampu mengikuti perkembangan dunia fashion. Sementara, untuk mengkontras kemampuan tanpa memberikan keterampilan yang berkesan berbeda, pola pantalon digunakan sebagai dasar modifikasi agar penjahit mengenal dan tertarik mengembangkan pola rok, apron, sarung, dll. Penjahit keliling diperkenalkan keilmuan arsitektural dengan memadukan program dan fungsi baru pada pantalon sehingga dapat digunakan pada keruangan lain. Temuan yang dihasilkan adalah terciptanya sebuah pantalon yang memiliki detail dari tipe bawahan berbeda dari perpaduan rok, sarung, apron dan pantalon tipe pensil. Kebaharuan dalam kegiatan Abdimas ini yakni: 1) Sebuah pantalon yang mencampur detail rok, sarung dan apron pada pantalon pensil 2) Kombinasi pola dengan teknik twisting dengan menghasilkan gambar manual, diolah menjadi digital dan diterjemahkan secara manual dengan kemampuan menjahit mitra 3) Bertambahnya fungsi pantalon dengan pencampuran detail. Sehingga diharapkan penjahit pantalon dapat meningkatkan kualitas dan kuantitas dari teknik perancangan pantalon, proses penjahitan produk dan menghasilkan produk yang sesuai dengan tuntutan perkembangan jaman. 


\section{Ucapan Terima Kasih}

Terima kasih kepada Direktur Direktorat Penelitian dan Pengabdian Masyarakat, Bapak Ir. Jap Tji Beng, Ph.D, Kepala Progam Magister Arsitektur Ibu Dr. Ir. Naniek Widayati M.T, dan juga pengerajin Gang Opek, atas kerjasama yang baik hingga terlaksananya Pengabdian Kepada Masyarakat ini.

\section{REFERENSI}

Bloch, P. H. (2011) Product Design and Marketing: Reflections After Fifteen Years. $J$ Prod Innov Manag Vol. 28, pg. 378-380.

Clarke, S., E., B. (2018) Outfitting Textiles, Fashion + Architecture: The Convergence + Interplay of Contruction + Engineering for the Human Form.

Doğan, C. (2012) Product Design for Sustainablility: Development of a New Graduate Course in Industrial Design. METU JFA, Vol. 2. Pg 313-329.

Gerritsen, A \& Riello, G. (2014) Writing Material Culture History. Bloomsbury

Oestigaard, T. (2004) Approaching Material Culture: A History of Changing

epistemologies. Journal of Nordic Archaelogical Science 14, pp. 79-87.

Publishing. Bloomsbury

Grassby, R. (2005) Material Culture and Cultural History. Journal of Interdisiplinary

History XXXV. Pg. 591-603.

Paksoy, H.; Yalcn, S. (2005) Architectural Inspirations in Fashion Design.Proceedings of the 3rd International Symposium of Interactive Media Design. January 5-7th.

Ravasi, D. \& Stigliani, I. (2012) Product Design: A Review and Research Agenda for Management Studies. International Journal of Management Reviews, 14(4), pp. 468-488.

Sunendar, D. (2017) Kamus Besar Bahasa Indonesia. Badan Pengembangan dan Pembinaan Bahasa. Kementerian Pendidikan dan Kebudayaan. Jakarta.

Zabala-Iturriagagoitia, J. M. (2012) New Product Development in Traditional Industries: Decision-Making Revised. Journal of Technology Management \& Innovation. Vol. 7. Issue 1.pg. $31-51$. 